\title{
Two Lighthouses to Navigate: Effects of Ideal and Counter-Ideal Values on Follower Identification and Satisfaction with their Leaders
}

\author{
Niels van Quaquebeke, Rudolf Kerschreiter, Alice E. Buxton, and \\ Rolf van Dick
}

In press at Journal of Business Ethics

\begin{tabular}{|l|l|}
\hline \multicolumn{2}{|l|}{ ERIM REPORT SERIES RESEARCH IN MANAGEMENT } \\
\hline ERIM Report Series reference number & ERS-2010-003-ORG \\
\hline Publication & January 2010 \\
\hline Number of pages & 32 \\
\hline Persistent paper URL & http://hdl.handle.net/1765/17702 \\
\hline Email address corresponding author & nquaquebeke@rsm.nl \\
\hline Address & Erasmus Research Institute of Management (ERIM) \\
& RSM Erasmus University / Erasmus School of Economics \\
& Erasmus Universiteit Rotterdam \\
& P.O.Box 1738 \\
& 3000 DR Rotterdam, The Netherlands \\
& Phone: + 31 10 408 1182 \\
& Fax: +31 10 408 9640 \\
& Email: info@erim.eur.nl \\
& Internet: $\quad$ www.erim.eur.nl \\
\hline
\end{tabular}

Bibliographic data and classifications of all the ERIM reports are also available on the ERIM website: www.erim.eur.nl 


\section{ERASMUS RESEARCH INSTITUTE OF MANAGEMENT}

\section{REPORT SERIES}

\section{RESEARCH IN MANAGEMENT}

\begin{tabular}{|l|l|}
\hline ABSTRACT AND KEYWORDS \\
\hline Abstract & $\begin{array}{l}\text { Ideals (or ideal values) help people to navigate in social life. They indicate at a very fundamental } \\
\text { level what people are concerned about, what they strive for, and what they want to be affiliated } \\
\text { with. Transferring this to a leader-follower analysis, our first Study (N = 306) confirms that } \\
\text { followers' identification and satisfaction with their leaders are stronger, the more leaders match } \\
\text { followers' ideal leader values. Study } 2 \text { (N = 244) extends the perspective by introducing the } \\
\text { novel concept of counter-ideals (i.e., how an ideal leader should not be) as a second, non- } \\
\text { redundant point of reference. Results confirm that a leader's match on ideal and on counter-ideal } \\
\text { values have independent effects in that both explain unique variance in followers' identification } \\
\text { and satisfaction with their leader. Study 3 (N = 136) replicates the previous results in an } \\
\text { experimental scenario study and provides evidence for the proposed causal direction of the } \\
\text { underlying process. We conclude that counter-ideal values might be an additional point of } \\
\text { reference that people use to triangulate targets above and beyond ideal values and discuss the } \\
\text { implications of our findings for value research and management. }\end{array}$ \\
\hline Free Keywords & $\begin{array}{l}\text { fit, followership, positive and negative forces, identification, ideals, leadership, satisfaction, } \\
\text { values }\end{array}$ \\
\hline Availability & $\begin{array}{l}\text { The ERIM Report Series is distributed through the following platforms: } \\
\text { Academic Repository at Erasmus University (DEAR), DEAR ERIM Series Portal } \\
\text { Social Science Research Network (SSRN), SSRN ERIM Series Webpage } \\
\text { Research Papers in Economics (REPEC), REPEC ERIM Series Webpage }\end{array}$ \\
\hline Classifications & $\begin{array}{l}\text { The electronic versions of the papers in the ERIM report Series contain bibliographic metadata } \\
\text { by the following classification systems: } \\
\text { Library of Congress Classification, (LCC) LCC Webpage } \\
\text { Journal of Economic Literature, (JEL), JEL Webpage } \\
\text { ACM Computing Classification System CCS Webpage } \\
\text { Inspec Classification scheme (ICS), ICS Webpage }\end{array}$ \\
\hline
\end{tabular}


Running head: TWO LIGHHOUSES

TWO LIGHTHOUSES TO NAVIGATE:

EFFECTS OF IDEAL AND COUNTER-IDEAL VALUES ON FOLLOWER IDENTIFICATION AND SATISFACTION WITH THEIR LEADERS

\author{
NIELS VAN QUAQUEBEKE \\ Erasmus University Rotterdam, Rotterdam School of Management, \\ Burgemeester Oudlaan 50; 3062 PA Rotterdam; The Netherlands \\ Tel: +31 1040819 22; e-mail: nquaquebeke@ rsm.nl \\ RUDOLF KERSCHREITER \\ Ludwig-Maximilians-University Munich, Psychology Department \\ Leopoldstr. 13, 80802 München, Germany \\ Tel: +49 892180 2274; e-mail: kerschreiter@psy.lmu.de \\ ALICE E. BUXTON \\ University of Hamburg, Psychology Department, \\ Von Melle Park 8, 20146 Hamburg, Germany \\ Tel: +49 4042838 4725; e-mail: buxton@ @respectresearchgroup.org

\section{ROLF VAN DICK} \\ Goethe University Frankfurt, Psychology Department, \\ Kettenhofweg 128, 60054 Frankfurt, Germany \\ Tel: +49 69798 23727; e-mail: van.dick@psych.uni-frankfurt.de
}

Author Note. The research was supported by a grant from the Stiftung wertevolle Zukunft. We are grateful to Johannes Ullrich, Steffen Giessner, and Suzanne van Gils for their valuable feedback on an earlier version of this paper. Parts of this paper were presented at the $13^{\text {th }}$ European Congress on Work and Organizational Psychology. Stockholm, 2007. 


\begin{abstract}
Ideals (or ideal values) help people to navigate in social life. They indicate at a very fundamental level what people are concerned about, what they strive for, and what they want to be affiliated with. Transferring this to a leader-follower analysis, our first Study $(N=306)$ confirms that followers' identification and satisfaction with their leaders are stronger, the more leaders match followers' ideal leader values. Study $2(N=244)$ extends the perspective by introducing the novel concept of counter-ideals (i.e., how an ideal leader should not be) as a second, non-redundant point of reference. Results confirm that a leader's match on ideal and on counter-ideal values have independent effects in that both explain unique variance in followers' identification and satisfaction with their leader. Study $3(N=136)$ replicates the previous results in an experimental scenario study and provides evidence for the proposed causal direction of the underlying process. We conclude that counter-ideal values might be an additional point of reference that people use to triangulate targets above and beyond ideal values and discuss the implications of our findings for value research and management.
\end{abstract}

Keywords: Fit, Followership, Positive and Negative Forces, Identification, Ideals, Leadership, Satisfaction, Values 
Two lighthouses to navigate: Effects of ideal and counter-ideal values on follower identification and satisfaction with their leaders

When people think about values, they think about the principles they live by and the goals they want to reach. Values guide our judgment as to what is right, good, and desirable. Put differently, values are a substantial part of our identity (Lord \& Brown, 2001; Rokeach, 1973) and consequently have a strong motivational and affective influence on our responses to the social world around us.

With the present research, we seek to investigate the importance of values in leaderfollower relationships. We posit that followers' identification and satisfaction with their leaders depend on whether they perceive that values they consider ideal for a leader are represented in their actual leaders. Moreover, we assume that not only a leader's match on ideal leader values, but also a leader's non-match on counter-ideal leader values, i.e., values a leader is not to represent, will be used by subordinates to "triangulate" their perceptions of and their responses toward this leader.

While the investigation of counter-ideal values is a unique contribution to the literature in itself, the present study also differs from studies on leader-follower value fit (Kristof-Brown, Zimmerman, \& Johnson, 2005) in that we do not ask if a leader represents followers' personal values but instead measure a leader's representation of values which followers regard as ideal for individuals holding leadership positions. This kind of conceptualization is somewhat similar to the leader categorization perspective in which subordinates' responses towards their leaders are argued to be the result of an implicit comparison of their leaders with an ideal leader prototype (e.g., Chhokar, Brodbeck, \& House, 2007; Epitropaki \& Martin, 2005; Kenney, Schwartz- 
Kenney, \& Blascovich, 1996). So far, however, respective leader prototypes are conceptualized along the dimensions of appearance, traits, and skills (Epitropaki \& Martin, 2004; Lord, Foti, de Vader, 1984; Offermann, Kennedy, \& Wirtz, 1994) - and not with a focus on values.

In summary, the first contribution we want to make is the investigation of whether followers' identification and satisfaction with their leaders will be determined by their perceived leaders' representation of ideal leader values. Secondly, and more importantly, we suggest a further, independent effect based on the (mis)match of counter-ideal leader values - which has neither been theoretically conceptualized nor empirically explored before. Ultimately, such theoretical broadening has the potential to offer new insights for theory and also for practice, in that corporate value communication might need to consider two independent sides: one focusing on ideal values and the other focusing on counter-ideal values.

\section{Values (at Work)}

A variety of value definitions has been suggested. Schwartz (1992: 2), for instance, states that "values are [...] desirable states, objects, goals, or behaviors, transcending specific situations and applied as normative standards to judge and to choose among alternative modes of behavior." Another, frequently used definition stems from Rokeach (1973: 5) who defines a value as "an enduring belief that a specific mode of conduct or end-state of existence is personally or socially preferable to an opposite or converse mode of conduct or end-state of existence."

In a nutshell, values are argued to lie at the basis of individuals' identities (Lord \& Brown, 2001; Rokeach, 1973). Because individuals tend to define themselves by the values they hold and because they attach great importance to their values, values have a large influence on the attitudes people express towards life and other people (Maio \& Olson, 1998). In that sense, 
values guide people in their own actions, but also serve as a criterion to evaluate other individuals' actions.

Often a distinction is made between general values and values concerning specific domains in life (van Quaquebeke, Zenker, \& Eckloff, in press). More specifically, values concerning work are often investigated separately because they are more proximal for the choices people make at work (Roe \& Ester, 1999). While it is generally stated that work values are specific expressions of general values in the work setting (Ros, Schwartz, \& Surkiss, 1999; Schwartz, 1999), little agreement has been found on the exact definition of work values. Based on Schwartz' (1992) definition of basic values, Ros et al. (1999: 54) define work values as "beliefs pertaining to desirable end-states (e.g. high pay) or behavior (e.g. working with people). The different work goals are structured by their importance as guiding principles for evaluating work outcomes and settings, and for choosing among different work alternatives." In their definition, work values are seen as verbal representations of individual goals in the work setting which are more specific than basic values. In other words, work values express a person's internalized belief about how he/she and others should or ought to behave at work (Meglino \& Ravlin, 1998; Roe \& Ester, 1999).

To develop hypotheses on how values affect leader-follower relationships, two lines of research can be drawn upon. For one, research on leader-follower value (in)congruence, secondly, research on leader categorization. Regarding the former, Phillips and Bedeian (1994), for instance, found that leader-follower similarity in attitudes (i.e., concerning goals in life) is positively related to leader-member exchange (see also Liden, Wayne, \& Stilwell, 1993). In a related vein, Senger (1971) found that supervisors rated subordinates' competences higher when subordinates were perceived as being similar on four main value dimensions, while Meglino, 
Ravlin, and Adkins (1989) found that subordinates reported more satisfaction and commitment when they perceived their supervisors' values to be congruent with their own (see also Meglino, Ravlins, \& Adkins, 1991). However, since only very few studies on person-supervisor fit exist and only a handful that actually included fit with respect to values, the empirical evidence for systematic effects is scattered at best (see the meta-analysis by Kristof-Brown et al., 2005). The second source for hypotheses on how values affect leader-follower relationships draws upon leader categorization research. Here, subordinates' responses towards their leaders are argued to be the result of an implicit comparison of their leaders with an ideal leader prototype (e.g., Chhokar et al., 2007; Epitropaki \& Martin, 2005; Kenney et al., 1996). The more subordinates perceive a target to represent their leader prototype, the more willing subordinates will be to follow the target's leadership. But, as mentioned before, respective theory and empirical evidence on leader prototype-match does not explicitly extend to the realm of values (cf. Epitropaki \& Martin, 2004; Lord, Foti, de Vader, 1984; Offermann, Kennedy, \& Wirtz, 1994). In the present paper, we draw from both approaches in that we focus on value fit but not in terms of an experienced fit of personal values per se but in terms of a fit of values seen as personally adequate for a specific role, in this case the leadership role.

Given that values are regarded as central to people's identity, it is surprising to note that to the best of our knowledge none of the previous studies have investigated the effect of value representation on identification. Indeed, finding that the leader represents one's esteemed "way of life (or work)" should make it easier to establish relational identification due to a sense of shared fate (Sluss \& Ashforth, 2007, 2008, cf. van Dick, Hirst, Grojean, \& Wiesecke, 2007). Likewise and as previous research already suggests, working with a leader who represents the values one considers ideal for a leadership position should elicit a feeling of satisfaction in that 
working with such a leader should be perceived as the fulfillment of a desired state (Meglino et al., 1991; cf. Wanous \& Lawler III, 1972). Therefore, we propose:

Hypothesis 1: The more a follower perceives his/her leader to represent the follower's ideal values for the leader domain, the more the follower identifies with and is satisfied with the leader.

In addition to outlining this ideal-value match, the core theoretical advancement of the present paper, is to go beyond this initial hypothesis by introducing counter-ideal values as a second point of reference. We conceptualize "counter-ideal" values as an independent counterconcept to “ideal” values. Following Rokeach's (1973) value definition, we define a counterideal value as an enduring belief that a specific mode of conduct or end-state of existence is personally or socially unacceptable.

Little is known about the relevance of counter-ideal values. Indeed, a literature search on “counter-ideal values" or semantic variants of it did not reveal any entries that investigate this matter. It seems to be the implicit assumption that formulating a value in its negative form represents the respective counter-ideal value. If that would be the case, then the additional investigation of counter-ideal values should not explain any additional variance beyond the effect of ideal values. A closer look into related research indicates, however, that ideal and counterideal values might have independent effects, and can thus be assumed to represent different values. Schwartz's (2006) circumplex model of values, for instance, posits that there are two independent dimensions of values (one dimension ranging from "openness to change" versus "conservation" while the other dimension ranges from "self-enhancement" to "selftranscendence"). Together, according to Schwartz, these two dimensions capture the whole space of possible values. An individual's ideal and counter-ideal values can thus be represented on 
separate dimensions with largely independent effects on attitudinal outcomes (cf. attitudes towards religiosity in Schwartz, \& Huismann, 1995).

While further evidence in the field of value research is scarce, looking into other fields of research provides preliminary evidence that the notion of counter-ideal leader values might be worthwhile to pursue. Research on leader categorization, for instance, posits that prototypical leader attributes are positively associated with effective leadership, while anti-prototypical leader attributes are negatively associated with effective leadership (Chhokar et al., 2007; Epitropaki \& Martin, 2004; House, Hanges, Javidan, Dorfman, \& Gupta, 2004; Lord, Foti, \& de Vader, 1984; Offermann, Kennedy, \& Wirtz, 1994). Importantly for the present paper, both, a leader's match on prototypical attributes and his or her match on anti-prototypical attributes, have independent effects on followers' evaluations and responses towards their leaders (as measured by LMX, work commitment, or general well-being in Epitropaki \& Martin, 2005).

More generally, the notion of positive and negative factors that guide individuals in their actions is also known in the area of attitude ambivalence and particularly in the domain of selfconcept research. Here it is contested that individuals hold different senses of self. While an "ideal self" determines what people strive for and are drawn to, the independent "undesired self" (Ogilvie, 1987) or "feared self" (Markus \& Nurius, 1986) determines what people repel against, are afraid of, and try to push themselves away from (Carver \& Scheier, 1998). Such psychological research can often be traced back to Heider's (1958) balance theory of the selfconcept in which he suggests that individuals are motivated to maintain balanced relationships, i.e., a system in which they agree with their friends and disagree with their enemies. In other words, Heider considers both positive and negative connections with others as equally important for individuals to make sense and maneuver in the social environment around them. 
This notion of counter-ideal leader values is further supported by anecdotal evidence which suggests that people use counter-ideals as a second standard for their judgment next to ideals, as exemplified in statements such as "My boss unfortunately lacks any kind of vision, but at least she/he is not egoistic." or my "My boss is visionary, however, she/he is also extremely egoistic". Put differently, it seems that the working together of a leader's representation against both standards adds more depth to the impression of a leader.

When we transfer the implication of the above research to leader values, we can posit that followers not only assess if their leaders represent their ideal values but also if they represent their counter-ideal values for the respective role. Both representations should have an independent effect on the degree to which followers identify with their leaders and are satisfied with their leadership. Indeed, much like the cited research on people's self-concepts, we can assume that people's perceptions of others are informed by push and pull factors which exert independent influences on the degree to which a sense of unity or shared fate, i.e., identification, is experienced. Likewise, satisfaction should be highest when push and pull factors are in balance, i.e., when people can avoid what they fear and can affiliate with what they desire (cf. Elliot \& Sheldon, 1997; Carver \& Scheier, 1998).

Hypothesis 2: The more a follower perceives his/her leader to represent the follower's counter-ideal values for the leader domain, the less the follower identifies with and is satisfied with the leader.

Hypothesis 3: The relationships described in Hypothesis 1 and 2 are nonredundant, in that both, ideal and counter-ideal values, are assumed to explain unique parts of variance.

In other words, we assume that people use ideal and counter-ideal values as two 
independent standards to assess the "position" of a target and consequently to decide in how far they want to approach or avoid it. Speaking metaphorically, much like lighthouses, we propose that it takes at least two reference points to navigate along the coast. When the night is dark, it is only the combination of two lighthouses that renders it possible to navigate one's ship towards a secure harbor or away from a dangerous reef.

\section{Overview of Studies}

To test our hypotheses, we conducted three studies. Study 1 aims to establish the basic idea that a leader's match on ideal leader values affects his/her employees' identification and satisfaction with the leader. Study 2 was designed to replicate the results of Study 1 and explores whether a leader's match on counter-ideal values has an additional independent effect on employees' identification and satisfaction with the leader. Study 3 was developed to replicate the previous findings using a different methodology (i.e., scenario experiment) which allows testing the proposed causal direction.

Study 1

Method

\section{Participants}

To obtain a large heterogeneous workforce sample, we decided to recruit participants via a major German email-portal website. A total of 354 participants completed the survey. We included only those participants who indicated that they currently reported to a specific leader $(N$ =306). The majority of the sample was female $(58 \%)$. Average age was 36 years $(S D=10.50)$. Nearly $42 \%$ had a university or college degree. Sixty-three percent had already finished a profession-qualifying degree or vocational training. The employment time spread around 15 years $(S D=10.38)$ with an average of six personally experienced leaders $(S D=3.67)$, of whom 
an average of $28 \%$ were female. Participants were employed in more than 20 different industries (approx. 70\% white-collar work).

\section{Measures}

To assess the degree to which participants perceived their leaders to match ideal leader values, we first asked participants to take a moment and write down the three most important basic values a leader should represent in the work domain (these indications would be taken later to check whether all participants had a clear understanding of the instruction). On the next page, we then presented a Venn-diagram via which participants indicated the degree to which their current leader's values would represent their previously stated ideal leader values (on the use of Venn-diagrams in organizational research see, for instance, Bergami \& Bagozzi, 2000; Shamir \& Kark, 2004, or van Quaquebeke \& Brodbeck, 2008). The Venn diagram consisted of two circles which start apart from each other and then come closer to each other in seven steps (1-7), finally completely overlapping in the last step. In our study, the left circle represented participants' perceptions of their current leader's values whereas the right circle represented participants' three previously indicated ideal leader values (Figure 1). It is by means of the pictorial measure that we sought to achieve a holistic ideal-match without having to provide lists of specific values which would have been excessively long and potentially prone to induce a social-desirability bias. Moreover, pictorial items function as "cognitive speed bumps" by requiring the participants to think carefully about what is being asked of them (Gardner, Cummings, Dunham, \& Pierce, 1998), and a potential common-item-type bias can be reduced when using different item-types for independent and dependent measures.

Insert Figure 1 about here 
Identification with leader was measured using Mael and Ashforth's (1992) 6-item organizational identification scale adapted to the current leader as the target of identification (cf. van Dick, Wagner, Stellmacher, \& Christ, 2004). The scale reflects the sense of unity that subordinates feel with their leaders. It encompasses items such as "When someone criticizes my leader, it feels like a personal insult", or "When I talk about my leader, I usually say 'we' rather than 'he or she"'. Responses were to be given on a 5-point disagree-agree scale.

Satisfaction with the leader was measured with Kunin's (1955) pictorial faces.

Participants were asked how satisfied they are with their current leader and to mark their degree of (dis)satisfaction by checking one of seven smileys ranging from very unhappy (-3) to very happy $(+3)$.

\section{Results}

Table 1 shows descriptive statistics and intercorrelations of the variables. The inspection of participants' written ideal values revealed that all participants had a correct understanding of the task. Ideal values indicated by the participants included aspects such as honesty, integrity, respect, knowledgeable, or loyalty. Most important for our Hypothesis 1, the results show a positive relationship between participants' perceptions of their leader's match on ideal leader values and the participants' identification $(r=.23, p<.001)$ as well as satisfaction $(r=.66, p<$ .001) with the leader. Hypothesis 1 can thus be considered supported.

Insert Table 1 about here

Study 2

The purpose of Study 2 was twofold. First, we wanted to replicate the findings of Study 1 
in an independent sample. Secondly and more importantly, Study 2 includes counter-ideals and aims at testing its independent effects on follower identification and satisfaction.

\section{Method}

\section{Participants}

To recruit a similar diverse workforce sample as in Study 1, we decided to recruit via text teasers on major German news websites. A total of 287 participants completed the survey. We included only those participants who indicated that they currently report to a specific leader $(N=$ 244). The majority of the sample was female $(56 \%)$. Average age was 35 years $(S D=10.67)$. Nearly $45 \%$ had university or college degree or were in the process of achieving one. $64 \%$ had already finished a profession-qualifying degree or vocational training. The employment time spread around 14 years $(S D=11.09)$ with an average of six personally experienced leaders $(S D=$ 4.94), of whom an average of $23 \%$ were female. Participants were employed in more than 20 different industries (approx. 80\% white-collar work).

\section{Measures}

Participants' perceptions of their leaders match on ideal leader values were assessed via Venn-diagrams described in Study 1. In addition, we also asked participants to take a moment and also write down the three values that a leader should not represent in the work domain (i.e., counter-values). Then, we provided a second Venn-diagram and asked participants to indicate the degree to which their leader represented these counter-values.

To measure the dependent variables, we used identical measures as in Study 1 (i.e., the Mael and Ashforth (1992) scale for measuring identification and the Kunin (1955) pictorial faces for assessing satisfaction). 


\section{Results}

Similarly to Study 1, we first examined participants' indicated ideal and counter-ideal values. Again, all participants seemed to have a clear understanding of the task. Ideal values again included aspects such as honesty, integrity, respect, knowledgeable, or loyalty. Counterideal values included aspects such as emotional instability, anti-sociality, unreliability, highhandedness, or arrogance. An exemplary individual (case 64) indicated, for instance, ideal leader values such as tolerance, clarity, and openness, and counter-ideal values such as impatience, intolerance, and dominance.

Table 2 shows the descriptive statistics and intercorrelations of the variables. Note that the match on ideal values and the match on counter-ideal values are associated with $r=-.55$ (cf. the exemplar participant above, i.e., tolerance and intolerance are exact opposites). While this relationship is significant and substantial, the amount of shared variation is only $30 \%$ which leaves enough room for unique contributions with respect to our main hypotheses. More important for Hypothesis 1, the intercorrelations reveal positive relationships between participants' perceptions of their leaders' match on ideal leader values and participants' identification $(r=.27, p<.001)$ and satisfaction $(r=.67, p<.001)$ with their leaders. In support of Hypothesis 2, the expected negative relationships were observed between participants' perceptions of their leader's match on counter-ideals and participants' identification $(r=-.28, p$ $<.001)$ and satisfaction $(r=-.65, p<.001)$ with the leader.

Insert Table $2 \& 3$ about here

To test whether the effects were independent, we used linear regression and analyzed the 
effects on identification and satisfaction when simultaneously entering leader's match of ideals and the leader's match of counter-ideals. Table 3 shows that both predictors remain significant when simultaneously entered into the regression equation. Furthermore, the $R^{2}$ change between Model 1 and Model 2 is significant for identification and satisfaction, suggesting that the addition of a leader's match of counter-ideal leader values explains a unique amount of variance beyond a leader's match of ideal leader values. Thus, Hypothesis 3 also finds support.

\section{Study 3}

Study 3 was designed to investigate whether the effects of a leader's match of ideal and counter-ideal leader values on satisfaction and identification with the leader may also be observed in an experimental setting. Specifically, we wanted to gain confidence in the predicted causal direction of the relationship by experimentally manipulating leader's match of ideal leader values independent of the leader's match of counter-ideal leader values and assess their effects on satisfaction and identification with the leader.

\section{Method}

\section{Participants and design}

One-hundred thirty-six German psychology students $(25 \%$ male, mean age $=24.13$ years, $S D=5.85)$ participated voluntarily in the study in partial fulfillment of experimental credit in a classroom context. The design was a 2 (leader's match of ideal leader values: high vs. low) $\times$ 2 (leader's match of counter-ideal leader values: high vs. low) between-subjects factorial design. Participants were randomly assigned to conditions.

\section{Procedure}

Participants received a short business scenario at the start of a lecture (adapted from van Knippenberg \& van Knippenberg, 2005). Participants were told that they would read about a 
situation in which values play a role. They were to imagine that they were in that particular situation and to answer our study questions accordingly. Participants read that they were to envision that they and other colleagues from their company had participated in a survey carried out by a nationwide cooperation of well-known research initiatives over the last five years. Participants then learned that the results of the nationwide survey suggest that a certain combination of leader values was ideal for a company and that these values foster employee engagement. On the other hand, they learned that results also showed that a certain combination of counter-ideal leader values exist that contribute to a lack of employee engagement. In addition to these general results, participants learned about the test scores of their current leader regarding the ideal leader values. In the leader's low match of ideal leader values condition, participants were informed that their direct leader at work did not at all possess these ideal leader values. In the leader's high match of ideal leader values condition, participants were informed that their leader did possess these ideal leader values to a nearly optimal degree. Hereafter, participants were also informed about their leader's match on the counter-ideal leader values. In the leader's low match of counter-ideal leader values condition, participants were informed that their leader did not at all possess these counter-ideal leader values. In the leader's high match of counterideal leader values condition, participants were informed that their leader did possess these counter-ideal leader values to a strong degree.

\section{Dependent measures}

We included two manipulation checks. One item checked whether the described leader's representation of ideal leader values was understood, asking: "My leader represents almost all of the values that an ideal leader should have". The other item checked whether the described leader's representation of counter-ideal leader values was understood, asking: "My leader 
represents almost all of the counter-ideal values that are hindering for a leader". Responses were given on a 5-point disagree-agree scale.

We included the same dependent measures as in the two preceding studies. Identification with the leader was measured via the 6-item Mael and Ashforth's (1992) organizational identification scale (1992) adapted to the current leader as the target of identification $(\alpha=.74 ; M$ $=2.86, S D=0.79)$. Satisfaction with the leader was measured with Kunin's (1955) pictorial faces $(M=3.24, S D=1.08)$.

\section{Results}

\section{Manipulation checks}

An Analysis of Variance (ANOVA) of the check on the ideal leader value representation manipulation indicated that the scenario leader representing the ideal values was rated as more representative of these ideal values $(M=4.39, S D=1.22)$ than the leader not representing the values $(M=1.52, S D=1.15), F(1,134)=198.17, p<.001, \eta^{2}=.60$.

An ANOVA on the check on the counter-ideal leader value representation manipulation indicated that the leader representing the counter-ideal values was rated as more representative of the counter-ideal values $(M=4.43, S D=1.22)$ than the leader not representing the counter-ideal values $(M=1.58, S D=1.21), F(1,132)=184.40, p<.001, \eta^{2}=.58$. Thus, we may conclude that our manipulations were successful.

\section{Identification with the leader}

An ANOVA on the identification with the leader scale yielded a significant main effect of the leader's match of ideal leader values, $F(1,132)=7.14, p=.008, \eta^{2}=.05$. Participants identified more with leaders matching ideal leader values $(M=3.03, S D=0.69)$ than with leader not matching ideal leader values $(M=2.68, S D=0.85)$. Most important for hypotheses, a 
significant main effect in the expected direction also emerged for the leader's match of counterideal leader values, $F(1,132)=3.92, p=.050, \eta^{2}=.03$. Participants identified more with leaders not matching counter-ideal leader values $(M=2.99, S D=0.78)$ than with leaders matching counter-ideal leader values $(M=2.72, S D=0.77)$. The interaction was not significant, $F(1,132)$ $=0.002, p=.964, \eta^{2}=.00$.

Satisfaction with the leader

An ANOVA on the satisfaction with the leader yielded a significant main effect of the leader's match of ideal leader values, $F(1,131)=54.79, p<.001, \eta^{2}=.30$. Participants were more satisfied with leaders matching ideal leader values $(M=3.77, S D=0.87)$ than with leader not matching ideal leader values $(M=2.68, S D=0.99)$. Again as predicted, a significant main effect in the expected direction also emerged for the leader's match of counter-ideal leader values, $F(1,131)=34.38, p<.001, \eta^{2}=.21$. Participants were more satisfied with leaders not matching counter-ideal leader values $(M=3.66, S D=0.94)$ than with leaders matching counterideal leader values $(M=2.78, S D=1.03)$. The interaction was again not significant, $F(1,131)=$ $0.19, p=.667, \eta^{2}=.00$.

\section{General Discussion}

With our three studies we set out to investigate the effect of ideal values and counterideal values on the identification and satisfaction of employees with their leaders. We argued that because values form the basis of people's identity (Lord \& Brown, 2001; Rokeach, 1973), they should have a strong motivational and affective influence on how people perceive and respond to the social world around them (Maio \& Olson, 1998). More specifically, we argued that followers are more likely to identify and to be satisfied with their leaders, the more they perceive that their leaders represent the values the followers cherish (Turner et al., 1987). Moreover, while research 
to date has predominantly focused on ideal values, we additionally incorporated the notion of counter-ideal values and posited that followers are less likely to identify and to be satisfied with their leaders, the more they perceive their leaders to represent counter-ideal values.

While Study 1 supports the first effect, Study 2 and 3 support both effects and moreover corroborate that the effects of ideal and counter-ideal values are independent in their influence on identification and satisfaction. Study 2 showed that the inclusion of both predictors explains significantly more variance than the one-predictor model. Due to the experimental design, Study 3 furthermore supports the causal relationship assumed in our hypotheses. Altogether, these studies extend previous research in that we provide first evidence that ideal and counter-ideal values are not situated on opposing poles of the same value dimension, but that counter-ideal values seem to form a non-redundant dimension in relation to ideal values.

\section{Limitations}

As with most empirical research, the present studies are not without limitations. Due to the nature of our measurement in Study 1 and 2, we were, for example, not able to directly compare the contents of people's ideal and counter-ideal values on a predetermined dimensional value space. Indeed, because the intercorrelations in Study 2 indicate some overlap in the representation of ideal and counter-ideal values of leaders (30\% shared variance), we should describe the relationship of ideal and counter-ideal values rather cautiously as "non-redundant". While the shared variance does not necessarily indicate that ideal and counter-ideal values are related on a content level (i.e., exact opposite poles on one dimension), the intercorrelation does at least point to the fact that their representation in practice is not completely independent.

Moreover, because we explicitly asked participants for ideal and counter ideal leader values, it seems a too big of a stretch to retrospectively map those specific leader-focused values 
upon Schwartz's (2006) more general value circumplex model and interpret the dimensionality. Future studies, which seek to tap into the content and relationship of ideal and counter-ideal values, thus seem well advised to commence their endeavors with established dimensional value instruments. Such procedure would, however, also require the transference of a value system into its negative counterpart - which has, to our knowledge, not yet been done for any of the available value universes. Nevertheless, it is particularly the investigation of counter-ideal values that we believe has the greatest potential to spur a new array of research questions.

Another potential shortcoming of our research pertains to the common source of our measurements in our two survey studies. While it needs to be noted that any common source bias should have worked against finding an independent significant effect of both constructs, i.e., ideal and counter-ideal values representation by the leader, and thus should have made it more difficult to find confirmation of our hypotheses, future research may nevertheless extend our hypothesis to external source data. Indeed, particularly absence, turnover, or supervisor ratings of effort are variables of high concern for the applied context. While we do not expect a different pattern, it would nevertheless be interesting to investigate the effect sizes a leader's match of ideal and counter-ideal values has for such outcomes.

\section{Implications and Future Directions}

Our research shows that ideal and counter-ideal values add independently to employees' evaluations of and responses to the social world around them. It therefore seems advisable to not only consider the values one wants to stand for, but also the ones one does not want to represent. Indeed, our results indicate that the combined communication of both aspects is more efficient at least when leaders manage to live up to them.

In future research it would now be interesting to explore factors that contribute to larger 
or smaller overlap in both ideal and counter-ideal values. In other words, under which conditions are ideal and counter-ideal values largely independent of each other and when are they the reverse of each other? As little is known on the relationship between ideal and counter-ideal values, hypotheses in this domain remain highly speculative. However, one may posit that individuals high in social identity complexity (Brewer, 1991) also have to accommodate many diverse values and beliefs (as opposed to individuals low in social identity complexity). Individuals high on identity complexity might therefore hold elaborate values and counter-values representations across independent value dimensions, while individuals low on complexity only differentiate between "right" or "wrong" on one dominant value dimension.

Inspired by the literature on person-environment fit, we can further assume that employees' growth need strength will moderate the found relationships in that employees with a high need for growth are likely to be more sensitive towards both, value and counter-value representation by their leaders, in an effort to develop into a more complete person (cf., Fried \& Ferris, 1987; Loher, Noe, Moeller, \& Fitzgerald, 1985). In addition, further research could also be directed at exploring differential moderating effects by looking at followers' and leaders' selfregulatory focus (see Kark \& Van Dijk, 2007). When followers are more prevention oriented, they might consider counter-ideal mismatches as more important than ideal matches, whereas promotion orientated followers might consider it more important that leaders match ideal leader values and less important that they do not match counter-ideals (cf. Lockwood, Jordan, \& Kunda, 2002). Vice-versa, it seems plausible to assume that promotion oriented leaders communicate more about reaching ideal values, while prevention oriented leaders are probably more concerned about avoiding counter-ideal values. It would thus be interesting if both are measured by the benchmark they provide, i.e., promotion oriented leader by their fulfillment of ideal values 
and prevention oriented leader by their non-fulfillment of counter-values, or if ideal and counterideal values matter equally in the assessment of both leader types.

On a final note, we believe that the present research also has the potential to inform research on more complex forms of organizational identification which not only cater for identification but also for issues such as disidentification or ambivalent identification (cf. Dukerich, Kramer, \& McLean Parks, 1998; Elsbach, 1999; Kreiner \& Ahsforth, 2004; Pratt, 2000). Squarely mapping upon our present conception, such studies explicitly state that "whereas identification consists of connecting (typically positive) aspects of the organization (whether at the molar or facet level) to oneself, disidentification consists of disconnecting (typically negative) aspects of the organization (whether at the molar or facet level) from oneself" (Kreiner \& Ashforth, 2004: 3). Furthermore, such studies posit that individuals, when finding themselves entangled in connecting and disconnecting aspects about the organization (cf. "imbalance" in Heider, 1958), are likely to have a sense of ambivalent identification with the organization (Kreiner \& Ashforth, 2004). Considering the above, it seems plausible that an organization's (but also a leader's) representation of ideal and counter-ideal values can be posited to lie at the very root of such more complex identification processes. Using such more complex conceptualizations of identification should thus enable future studies to disentangle and illustrate more of the independent workings of ideal and counter-ideal values at work.

All in all, the domain of counter-ideal values and their relevance in combination with ideal values appears to be a promising area for further research. Maybe ideal and counter-ideal values are two sides of the same coin, but, as we have shown here, one side of the coin is not necessarily the negative embossing of the other. It is thus important to look at both sides when having to decide how much a coin is worth. 


\section{References}

Bergami, M., \& Bagozzi, R. P.: 2000, 'Self-categorization, affective commitment and group selfesteem as distinct aspects of social identity in the organization', British Journal of Social Psychology 39, 555-577.

Brewer, M. B.: 1991, 'The social self: On being the same and different at the same time', Personality and Social Psychology Bulletin 17, 475-482.

Carver, C. S., \& Scheier, M. F. 1998.: On the self-regulation of behavior, (Cambridge: Cambridge University Press).

Chhokar, J. S., Brodbeck, F. C., \& House, R. J.: (eds.). 2007, Culture and leadership across the world: The GLOBE book of in-depth studies of 25 societies, (Mahwah, NJ: LEA Publishers).

Dukerich, J. M., Kramer, R., \& McLean Parks, J.: 1998. 'The dark side of organizational identification', in D. A. Whetten \& P. C. Godfrey (eds.), Identity in organizations: Building theory through conversations, (Thousand Oaks, CA: Sage), p. 245-256.

Elliot, A. J., \& Sheldon, K. M.: 1997, 'Avoidance achievement motivation. A personal goals analysis', Journal of Personality and Social Psychology 73, 171-185.

Elsbach, K. D.: 1999, ‘An expanded model of organizational identification’, Research in Organizational Behavior 21, 163-200.

Epitropaki, O., \& Martin, R.: 2004, 'Implicit leadership theories in applied settings: Factor structure, generalizability, and stability over time', Journal of Applied Psychology 89, 293-310.

Epitropaki, O., \& Martin, R.: 2005, 'From ideal to real: A longitudinal study of the role of implicit leadership theories on leader-member exchanges and employee outcomes', 
Journal of Applied Psychology 90, 659-676.

Fried, Y., \& Ferris, G.R.: 1987, 'The validity of the job characteristics model: A review and meta-analysis', Personnel Psychology 40, 287-322.

Gardner, D. G., Cummings, L. L., Dunham, R. B., \& Pierce, J. L.: 1998, 'Single-item versus multiple-item measurement scales: An empirical comparison', Educational and Psychological Measurement 58, 898-915.

Heider, F.: 1958, The psychology of interpersonal relations (New York: Wiley).

House, R. J., Hanges, P. J., Javidan, M., Dorfman, P., \& Gupta, V.: 2004, 'Culture, leadership, and organizations: The GLOBE study of 62 societies', (Thousand Oaks, Calif.: Sage Publications).

Kark, R., \& Van Dijk, D.: 2007, 'Motivation to lead, motivation to follow: The role of the selfregulatory focus in leadership processes', Academy of Management Review 32, 500-528.

Kenney, R. A., Schwartz-Kenney, B. M., \& Blascovich, J.: 1996, 'Implicit leadership theories: Defining leaders described as worthy of influence', Personality \& Social Psychology Bulletin 22, 1128-1143.

Kreiner, G. E., \& Ashforth, B. E.: 2004, 'Evidence toward an expanded model of organizational identification', Journal of Organizational Behavior 25, 1-27.

Krishnan, V.R.: 2002, ‘Transformational leadership and value system congruence', International Journal of Value-Based Management 15, 19-33.

Kristof-Brown, A.L., Zimmerman, R.D., \& Johnson, E.C.: 2005, 'Consequences of individuals' fit at work: A meta-analysis of person-job, person-organization, person-group, and person-supervisor fit', Personnel Psychology 58, 281-342.

Kunin, T.: 1955, 'The construction of a new type of attitude measure', Personnel Psychology 8, $65-77$. 
Liden, R.C., Wayne S.J., \& Stilwell D.: 1993, 'A longitudinal study on the early development of leader-member exchanges', Journal of Applied Psychology 78, 662-674.

Lockwood, P., Jordan, C. H., \& Kunda, Z.: 2002, 'Motivation by positive or negative role models: Regulatory focus determines who will best inspire us', Journal of Personality and Social Psychology 83, 854-864.

Loher, B.T., Noe, R.A., Moeller, N.L., \& Fitzgerald, M.P.: 1985, ‘A meta-analysis of the relationship of job characteristics to job satisfaction', Journal of Applied Psychology 70, 280-289.

Lord, R. G., \& Brown, D. J.: 2001, 'Leadership, values, and subordinate self-concepts', The Leadership Quarterly 12, 133-152.

Lord, R. G., Foti, R. J., \& de Vader, C. L.: 1984, 'A test of leadership categorization theory: Internal structure, information processing, and leadership perceptions', Organizational Behavior \& Human Performance 34, 343-378.

Mael, F., \& Ashforth, B. E.: 1992, 'Alumni and their alma mater: A partial test of the reformulated model of organizational identification', Journal of Organizational Behavior $13,103-123$.

Maio, G. R., \& Olson, J. M.: 1998, 'Values as truisms: Evidence and implications', Journal of Personality and Social Psychology 74, 294-311.

Markus, H., \& Nurius, P.: 1986, ‘Possible selves’. American Psychologist 41, 954-969.

Meglino, B. M., \& Ravlin, E. C.: 1998, 'Individual values in organizations: Concepts, controversies, and research', Journal of Management 24, 351-389.

Meglino, B.M., Ravlin E.C., \& Adkins C.L.: 1989, 'A work values approach to corporate culture: A field test of the value congruence process and its relationship to individual outcomes', Journal of Applied Psychology 74, 424-432. 
Meglino, B. M., Ravlin, E. C., \& Adkins, C. L.: 1991, 'Value congruence and satisfaction with a leader: An examination of the role of interaction', Human Relations 44, 481-495.

Offermann, L. R., Kennedy, J. K., \& Wirtz, P. W.: 1994, 'Implicit leadership theories: Content, structure, and generalizability', The Leadership Quarterly 5, 43-58.

Ogilvie, D. M.: 1987, 'The undesired self: A neglected variable in personality research', Journal of Personality and Social Psychology 52, 379-385.

Phillips, A.S., \& Bedeian A.G.: 1994, 'Leader-follower exchange quality: The role of personal and interpersonal attributes', Academy of Management Journal 37, 990-1001.

Podsakoff, P. M., Podsakoff, N. P., MacKenzie, S. B., \& Lee, J.-Y.: 2003, 'Common method biases in behavioral research: A critical review of the literature and recommended remedies', Journal of Applied Psychology 88: 879 - 903.

Pratt, M. G.: 2000, 'The good, the bad, and the ambivalent: Managing identification among Amway distributors', Administrative Science Quarterly 45, 456-493.

Roe, R. A., \& Ester, P.: 1999, 'Values and work: Empirical findings and theoretical perspective', Applied Psychology: An International Review 48, 1-21.

Rokeach, M.: 1973, The nature of human values, (New York: Free Press).

Rokeach, M.: 1979, Understanding human values, (New York: The Free Press).

Ros, M., Schwartz, S. H., \& Surkiss, S.: 1999, 'Basic individual values, work values, and the meaning of work', Applied Psychology: An International Review 48, 49-71.

Schwartz, S. H.: 1999, 'A theory of cultural values and some implications for work', Applied Psychology: An International Review 48, 23-47.

Schwartz, S. H.: 2006, 'Basic human values: Theory, measurement, and application', Revue francaise de sociologie 47, 1-19.

Schwartz, S. H.: 1992, 'Universals in the content and structure of values: Theory and empirical 
tests in 20 countries', in M. P. Zenna (ed.), Advances in Experimental Social Psychology, Vol. 25, (New York: Academic Press), p. 1-65.

Senger J.: 1971, 'Managers' perceptions of subordinates' competence as a function of personal value orientations', Academy of Management Journal 14, 415-423.

Shamir, B., \& Kark, R.: 2004, 'A single-item graphic scale for the measurement of organizational identification', Journal of Occupational \& Organizational Psychology 77, 115-123.

Sluss, D. M., \& Ashforth, B. E.: 2007, 'Relational identity and identification: Defining ourselves through work relationships', Academy of Management Review 32, 9-32.

Sluss, D.M., \& Ashforth, B.E.: 2008, 'How relational and organizational identification converge: Processes and conditions', Organization Science 19, 807-823.

Turner, J. C., M. A. Hogg, P. J. Oakes, S. D. Reicher and M. S. Wetherell: 1987, Rediscovering the Social Group: A Self-Categorization Theory (Cambridge, MA: Basil Blackwell, Inc.). van Dick, R., Hirst, G., Grojean, M., \& Wiesecke, J.: 2007, 'Relationship between leader and follower organizational identification and implications for follower attitudes and behavior', Journal of Occupational and Organizational Psychology 80, 133-150.

van Dick, R., Wagner, U., Stellmacher, J., \& Christ, O.: 2004, 'The utility of a broader conceptualization of organizational identification: Which aspects really matter?', Journal of Occupational \& Organizational Psychology 77, 171-191.

van Knippenberg, B., \& van Knippenberg, D.: 2005, 'Leader self-sacrifice and leadership effectiveness: The moderating role of leader prototypicality', Journal of Applied Psychology 90, 25-37.

van Quaquebeke, N., \& Brodbeck, F. C.: 2008, 'Entwicklung und erste Validierung zweier Instrumente zur Erfassung von Führungskräfte-Kategorisierung im deutschsprachigen 
Raum [Development and first validation of two scales to measure leader categorization in German-speaking countries]', Zeitschrift für Arbeits- und Organisationspsychologie 52, 70-80.

van Quaquebeke, N., Zenker, S., \& Eckloff, T.: in press, 'Find out how much it means to me! The importance of interpersonal respect in work values compared to perceived organizational practices', Journal of Business Ethics, (online first) doi:10.1007/s10551008-0008-6.

Wanous, J. P., \& Lawler III, E. E.: 1972, 'Measurement and meaning of job satisfaction'. Journal of Applied Psychology 56, 95-105. 
Table 1

Descriptive Statistics and Correlations, Study 1

\begin{tabular}{lllll}
\hline & $M$ & $S D$ & 1 & 2 \\
\hline 1. Leader Match on Ideal Leader Values & 3.73 & 1.77 & -- & \\
2. Identification with Leader & 2.18 & 0.80 & $.23^{* * *}$ & $(.79)$ \\
3. Satisfaction with Leader & 4.33 & 2.06 & $.66^{* * *}$ & $.45^{* * *}$ \\
\hline
\end{tabular}

Note. $N=306$; Cronbach's $\alpha$ are indicated in parentheses where applicable; $* * * p<.001$ 
Table 2

Descriptive Statistics and Correlations, Study 2

\begin{tabular}{|c|c|c|c|c|c|}
\hline & $M$ & $S D$ & 1 & 2 & 3 \\
\hline 1. Leader Match on Ideal Leader Values & 3.60 & 1.82 & -- & & \\
\hline 2. Leader Match on Counter-Ideal Leader Values & 3.21 & 1.99 & $-.55 * * *$ & -- & \\
\hline 3. Identification with Leader & 2.12 & 0.74 & $.27 * * *$ & $-.28 * * *$ & $(.71)$ \\
\hline 4. Satisfaction with Leader & 4.21 & 2.14 & $.67 * * *$ & $-.65 * * *$ & $.41 * * *$ \\
\hline
\end{tabular}

Note. $N=244$; Cronbach's $\alpha$ are indicated in parentheses where applicable; $* * * p<.001$ 
Table 3

Results of Multiple Regression Analysis of Identification and Satisfaction with the Leader Onto Leader Match on Ideal and Counter-

Ideal Values in Study 2.

Identification with Leader

B

SE B

$\beta$

.11

.03

$.27 * * *$

.08

$19.70^{* * *}$

.07

$.03 \quad .18^{*}$

$-.07$

.03

$-.18^{*}$

.02

$6.11 *$

.10
Satisfaction with Leader

$B \quad S E B \quad \beta$
.06

$.67 * * *$

.45

$198.48 * * *$
$\Delta R^{2}$

$\Delta F$

Total $R^{2}$

Note. $N=265 ; * p<.05 ; * * p<.01 ; * * * p<.001$; 
Figure 1

Venn-Diagram to Measure the Degree to Which a Participant's Current Leader Represents the Participant's Ideal Leader Values

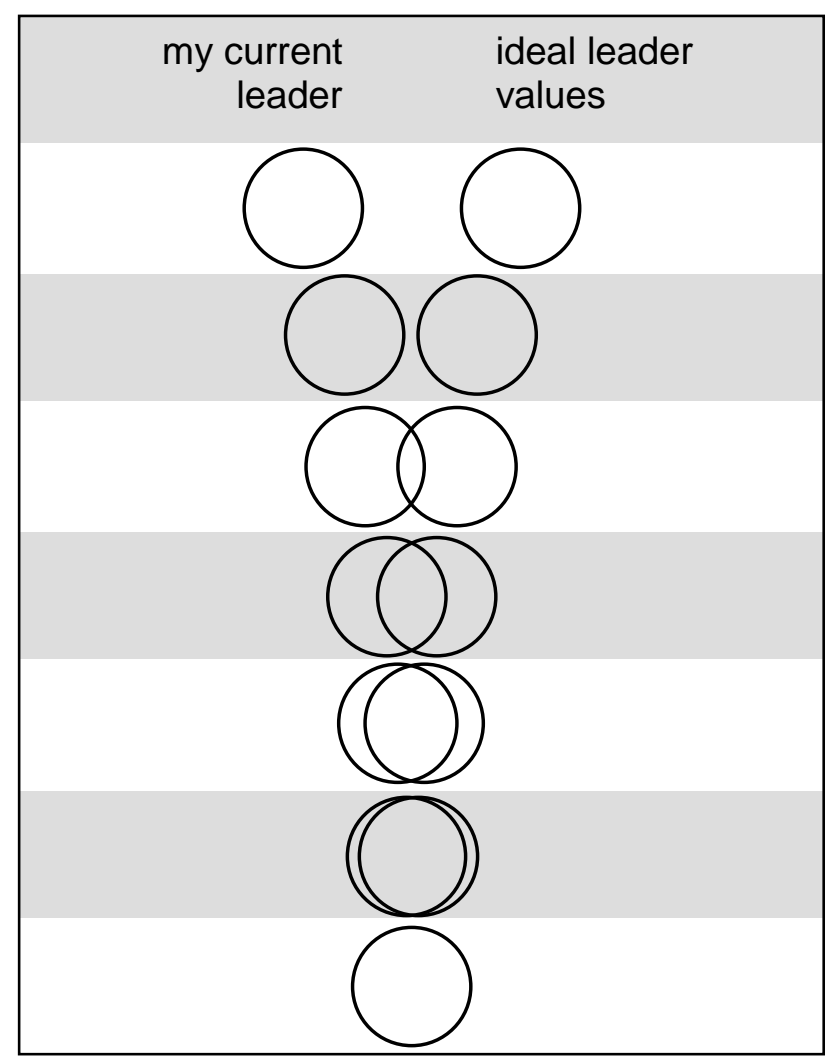




\section{Publications in the ERIM Report Series Research* in Management}

\section{ERIM Research Program: "Organizing for Performance"}

2010

Investigating the Perceptions of Credit Constraints in the European Union

Erik Canton, Isabel Grilo, Josefa Monteagudo, and Peter van der Zwan

ERS-2010-001-ORG

http://hdl.handle.net/1765/17699

Two Lighthouses to Navigate: Effects of Ideal and Counter-Ideal Values on Follower Identification and Satisfaction with their Leaders

Niels van Quaquebeke, Rudolf Kerschreiter, Alice E. Buxton, and Rolf van Dick

ERS-2010-003-ORG

http://hdl.handle.net/1765/17702

* A complete overview of the ERIM Report Series Research in Management: https://ep.eur.nl/handle/1765/1

ERIM Research Programs:

LIS Business Processes, Logistics and Information Systems

ORG Organizing for Performance

MKT Marketing

F\&A Finance and Accounting

STR Strategy and Entrepreneurship 